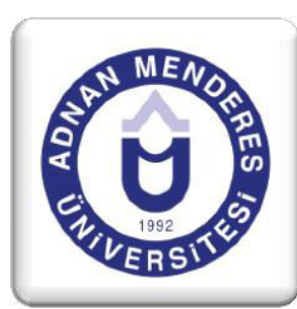

\title{
Malatya Büyükşehir Belediyesi: Arakentten Bütünkente Bir Dönüşüm Hikâyesi
}

\section{Malatya Metropolitan Municipality: Transformation Story From Precity To Entire City}

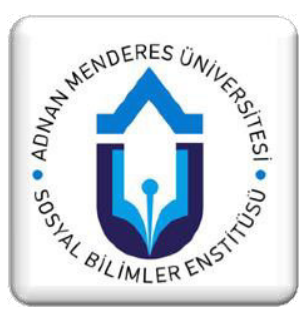

\section{Özet}

Malatya kenti Anadolu'nun kuzeyi ile güneyini, batısı ile doğusunu birleştiren bir kavşak noktasındadır. Bu nedenle tarihin ilk dönemlerinden beri hep stratejik bir yerleşim merkezi durumunda olmuştur. Cumhuriyet döneminde de bu nedenle öncü sanayiler bu kente kurulmuş ve bölgesel kalkınmanın da yardımcısı olması hedeflenmiştir.

Ancak kentin hinterlandındaki diğer kentlerden beslenememesi başta olmak üzere çeşitli nedenlerden dolayı beklenen büyümeyi (ekonomik, demografik vb.) gerçekleştirememiştir. Geçen süreç içerisinde merkezi yönetimin son dönemlerdeki politikalarıla kente büyükşehir statüsü verilmiştir. Yalnızca nüfus büyüklüğüne dayalı olarak alınan bu kararın ne gibi etkileri olacağı bu çalışmanın ana konusunu oluşturmaktadır. Çalışmada yapılan tesbitler yalnızca Malatya kentine değil bu yasadan yararlanan diğer kentler için de geçerli olabilecek unsurları içermektedir.

Anahtar Kelimeler: Büyükşehir Belediyesi, Bölgesel Kalkınma, Kent Planlaması, Nüfus Büyüklüğü

\begin{abstract}
The city of Malatya is at the crossroads uniting the North and South and the West and the east of Anatolia. That's why it has always been a strategic center of settlement since the early history. The Pioneer industries were established in this city and they were aimed to support the regional development in the Republican Period because of the reason mentioned above.
\end{abstract}

But the city did not achieve the expected growth growth (economic, demographic etc.) because of the reasons that it wasn't subsidized by the other cities in its hinterland and etc. In the meantime, the city has taken the statue of metropolitan municipality as a result of central government politics. The effects of this decision made by only taking the population into consideration will be the focus of this study, the findings of this study is not only about the city of Malatya but they also contain factors that are current for the other cities benefiting from the law.

Keywords: Metropolitan Municipality, Regional Development, Urban Planning Scheme, Population Size

\section{Berkan \\ $D E M I R A L^{*}$ \\ Hakan \\ $E V I N^{* *}$}

*Prof. Dr.

Trakya Üniversitesi

**Doç. Dr.

Adlyaman

Üniversitesi 


\section{GíRiş}

Birleşmiş Milletler yirminci yüzyılı kentler yüzyılı ilan ettiğinde beraberinde çok sayıda tartışmayı da getirmişti. Ancak yeni bin yıl daha şimdiden kentler bin yılı olarak ilan edildi bile. Bundan yaklaşı olarak 8500 yıl önce ilk kentler ortaya çıkmaya başladıklarında insanlık tarihine bu kadar büyük damga vuracakları tahmin edilemezdi. Ancak zaman içerisinde kentlerde yaşanan sorunlar tüm insanlığın ortak sorunları haline geldiler.

Tarihte kentlerin nüfuslarının yoğunlaşması beraberinde sürdürülebilirlik tartışmalarını da getirmiştir. Bu sorunu belki de ilk yaşayan kent 1 milyona aşkın nüfusuyla ilk çağ Roma'sı olmuştur. Roma bu dönemde bir taraftan artan nüfusuyla ilgi odağı haline gelirken bu nüfusun ihtiyaçlarının karşılanmasında yaşanan güçlükler yalnız kentin değil koca imparatorluğun da sonunu getirmiştir. Roma'dan sonra çok uzun bir süre bir daha hiç bir kent bu nüfusu yakalayamayacaktır.

Kentsel devrimin ikinci ayağı sanayi devrimiyle yaşanacaktır. Özellikle Avrupa'da ortaçağın içine kapanık kalan kentleri bir taraftan feodalitenin yıkılması öte yandan başlayan sanayi devrimiyle kentsel mekanlara büyük yığılmalarla yeniden karşılaşmıştır. $\mathrm{Bu}$ dönemde öne çıkan kent ise Londra olmuştur. Kentsel devrimin bu ikinci aşamasında da insan yığınlarının ihtiyaçlarının istenilen ölçüde karşılanabilmesi önemli bir sorun haline gelmiştir. O dönemde Ebenezer Howard gibi kent plancıları sorunun çözümü için ara kentlerin kurulmasını ve kentlerin etrafına yeşil bir duvar çekilmesini önermişlerdir. Yeni kentler olarak adlandırılan bu yapılar süreç içerisinde pek çok ülkede denenmiştir. Türkiye'de de iki kez köy kent adıyla denenmiş ancak başarılı olamamıştır.

Büyük kent olgusu üçüncü kez 1960’11 yıllarda yeniden gündeme gelmiştir. Büyük kentlerin yönetimine ilişsin tartışmalar 1970'li yıllarda giderek artmış ve 1980'li yıllarda metropolitan yönetim yapılarının kurulmasıla gündemin merkezine oturmuştur.

Türkiye'nin de bu gelişmelerden uzak kalması beklenemezdi. Gerçi sürecin önceki dönemlerine bakıldığında ülkelerin kentleşme oluşumları çok büyük benzerlikler göstermemektedir. Avrupa'nın ki, Afrika'ya; Asya'nın ki Latin Amerika'ya büyük ölçüde benzememektedir. Bir tarafta yüzyılı aşkın uzun soluklu bir süreç söz konusu iken öte yandan bağımlı kentleşme diye adlandırılan ve çok kısa bir döneme sıkıştırılmış bir süreç basamağından söz edilebilmektedir.

Üçüncü bin yılın başlangıcı ile birlikte bu kez eşi benzeri olamayan büyüklükte ana kentsel alanlar ortaya çıkmaya başladı. Bu alanların ortaya çıkmaya başlamasında merkezi yönetimlerin benimsedikleri kentsel politikaların önemi çok büyüktür. Geçmişte sürekli olarak küçüğün güzel olduğundan bahsedilse de artık büyüğün de ölçeği olduğu kabul edilmeye başlamıştır.

Küreselleşmenin etkisiyle dünya politika sahnesinde önemli değişimler yaşanmaya başlamıştır. Bu değişimlerden ilki daha önce siyaset sahnesinde görülmeyen devlet, piyasa ve toplumla ilişkili aktörlerin sahne almaya başlamasıdır. İkinci olarak görülen değişim günümüz siyaset sahnesinde oynanan oyunun artık tek bir düzlemde değil çoklu düzlem de oynanmaya başlamasıdır. Yine bu oyunda renkli, göreceli olarak farklı güçlere sahip çok sayıda aktörün sürekli olarak kaymalarla alana indikleri gözlemlenmektedir. Yine ulusal ve uluslararası arenada sınırların yeniden tanımlandı̆̆ına şahit olunmaktadır. Yeni aktörler artık yeni mekanlarda yeni rollerini sahnelemektedirler. Son olarak da bu değişim klasik yönetim anlayışını da önemli ölçüde etkisiz bırakmıştır. Geleneksel izlemler, denetim ve idare yöntemleri artık etkisiz hale gelmişlerdir.

Kentler bir taraftan yeni küresel arenanın rekabetçi temel aktörleri haline gelirken, öte yanda Perraux'un kalkınma kutupları modelleri başta olmak üzere gelişimde yaşanan dengesizliklerin çözümüne yönelik olarak ele alınması gereken ideal mekanlar olduklarına ilişkin vurgular da artmaya devam etmiştir. Bu durum kaynakların adil dağılımı ve kalkınmada sürdürülebilirliğin sağlanması açısından kentleri merkeze yerleştiren anlayışlarda bir artışa neden olmuş görünmektedir.

\section{MALATYA KENTI}

Yaklaşı on bin yıllık bir tarihe sahip olan ve 2 bin yıldır da kendi adıyla tarihte sahne alan Malatya kenti 1.241.000 hektarlık yüzölçümü, yaklaşık 750.000 nüfusu ile Türkiye'nin önemli yerleşim alanlarından 
biridir. Ancak son dönemlerde özellikle sosyoekonomik göstergelerde gözle görülür bir düşüş içerisindedir. Türkiye'deki kentler arasındaki sırası 1996 yılında 38. iken 2003 yılında 41'ciligğe, 2010 ise 47'ciliğe gerilemiştir. Oysa Malatya, toprak büyüklüğü ve nüfus açısından Türkiye ortalamasının üzerinde bir kenttir.

12.412 km2'lik bir yüz ölçümüne sahip olan Malatya, yüz ölçümü büyüklüğü bakımından Türkiye'nin 23. büyük vilayeti durumundadır. 35 34` ve $3903^{`}$ Kuzey enlemleri ile $3845^{\prime}$ ve $3908^{\prime}$ Doğu boylamları arasında kent; Sultan suyu ve Sürgü Çayı Vadileriyle Akdeniz'e, Tohma Vadisiyle İç, Anadolu’ya, Frrat Vadisiyle Doğu Anadolu’ya açılarak bu bölgeler arasında bir geçiş, alanı oluşturur.

Şekil1: Malatya Haritas1

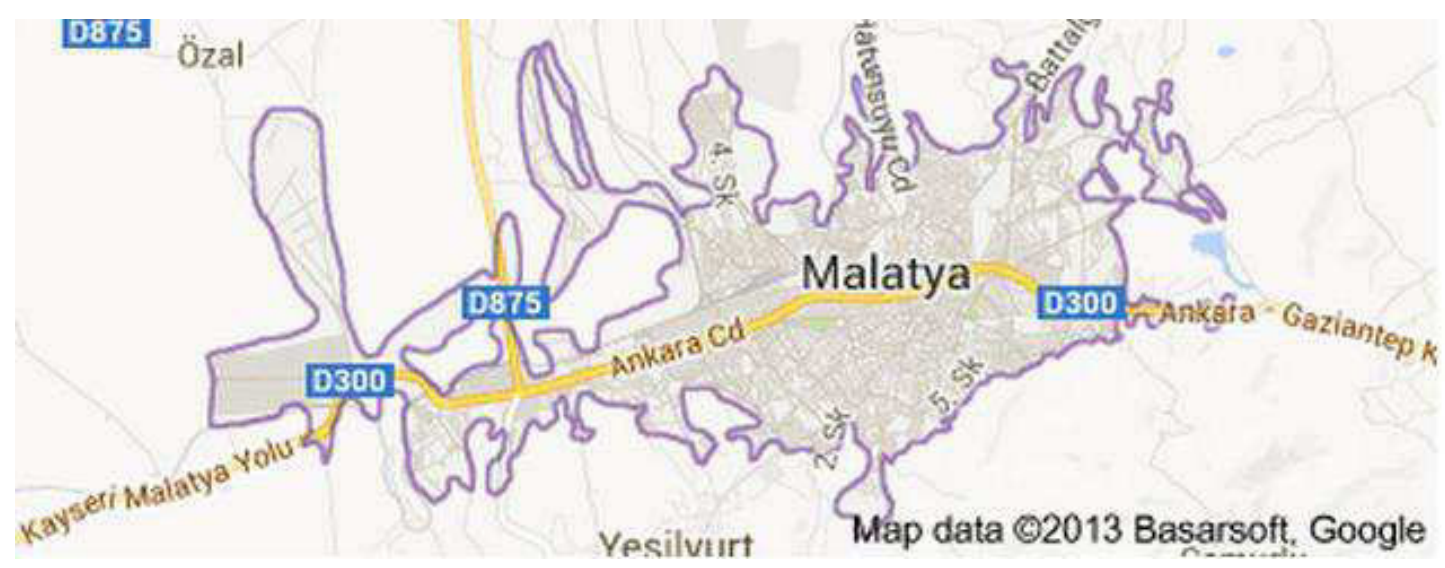

\section{TARIHÇE}

“Avrupa'nın doğusuyla Asya'nın batısını bir araya getiren jeopolitik ve jeostratejik yapısından dolayı Anadolu daima bir kavşak noktası olmuştur. Bu coğrafyanın en kilit geçiş noktalarından birinin merkezinde de Malatya yer almaktadır. Doğuda en eski ulaşım yolu; Malatya-Sivas üzerinden Erzurum'a, oradan da Kafkasya'ya uzanan yoldur. Buna, Karasu Aras yolu da denilmektedir. Öte yandan Güneydoğu'ya, Malatya ve Diyarbakır üzerinden Mezopotamya'ya uzanan yol önemlidir. Malatya'dan doğuya doğru Murat, Karasu Van Gölü diğer tabii bir önemli yoldur. Diğer önemli bir yol ise Güneyden gelip Malatya'da düğümlenen Malatya- Kahramanmaraş arasında Torosların çok kesif göründükleri bir sahada, akış yönleri farklı vadilerin takip ettiği tabii bir koridor boyunca uzanmaktadır. Güneyde dağlar arasında açılmış bir başka yol, Adıyaman üzerinden Urfa'yı Malatya'ya bağlamaktadır.

Belirtilen yollar, Malatya'da birleşerek kuzeyde Kafkasya'ya, güneyde Çukurova, Mezopotamya ve Suriye'ye, batıda Ege sahillerine, doğuda İran ve uzak doğuya kadar uzanmaktadır. Bu yollar, Akad İmparatoru Sargon zamanından beri işlemekteydi. Hititler zamanında da işlemekte olan bu yoldan Hitit Krallarının geçerek Anadolu üzerindeki devletlerle savaştığı bilinmektedir. Hitit Kralı Şuppililiuma'nın bu yoldan geçerek Aşağı Fırat boylarına indiği, dolayısıyla Malatya civarında Fırat Nehrini geçtiği kaynaklarca belgelenmektedir.

Malatya'nın tarihçesi de bu nedenle M.Ö. 7000'li yıllara kadar dayanmaktadır. Kent sırasıyla Akad, Hitit, Roma, Bizans, Arap, Selçuklu (Büyük ve Anadolu), Osmanlı dönemlerini yaşamıştır. Roma döneminde Fırat kıyısına yerleştirilen iki büyük lejyonun etkisiyle eyalet başkenti haline gelerek büyümüştür. Ancak geçiş noktası olması özelliğiyle sürekli işgal tehlikesi yaşaması kentin önemli bir büyüme gerçekleştirmesinin önüne geçmiştir.

Osmanlı'nın son dönemlerinde Malatya merkez kazasının nüfusunun 133.244 olduğu (1892), tüm Malatya sancağının nüfusunun ise 216.280 olduğu belirtilmektedir. 
Cumhuriyet dönemine gelindiğinde Anadolu'nun işgali döneminde işgale uğramayan az sayıda kentten biri olarak ön plana çıkmıştır. 1924 Anayasası ile (9. Madde) il olan Malatya savaşın etkilerini çevresindeki pek çok kente oranla az yaşamanın faydalarını önemli ölçüde görmüştür.

\subsection{MALATYA BELEDIYYSİ}

Malatya'da Osmanlı Devletinde önceleri kadılar tarafindan yürütülen belediye işleri, 1855 y1lında kurulan Şehremaneti ile bu daireye verilmiştir. Malatya Belediyesinin (O günkü adıyla Sancağı) kesin olmamakla birlikte 1860'lı yılların sonuna doğru kurulduğu tahmin edilmektedir. Diyarbakır Salnamelerinde Malatya Sancağının ilk belediye başkanlığını 1876 yılında Ömer Efendi’nin yaptığı kaydına rastlanmaktadır. Daha sonra sırasıyla 1877'de Sıdık Bey'in, 1883- 1891 yılları arasında Ali Bey'in belediye Başkanlığı görevinde bulunduğu, aynı yıl içinde Sancakta Belediye teşkilatının kurulduğu, reisliğe Hacı İbrahim Efendi'nin seçildiği, Belediye Encümeninin dört azadan (üye), bir kâtip, iki müfettiş, bir belediye tabibi kadrosundan teşekkül ettiği bilinmektedir.

1894-1895 Mamura tül Aziz(Elazığ) Salnamesi'nde bu yıllar arasında Ali Bey'in belediye reisi olduğu, dört belediye encümen azası, üç çavuş, bir sandık emini ve bir belediye tabibi kadrosunun bulunduğu bilgisi yer almaktadır. Yine aynı kaynaklarda 1907 yılında Malatya Belediye Başkanlığına Haşim Bey'in seçildiği, devamında sirasiyla Azizlerin Mustafa Ağa'nın 1908- 1914, Arpacizade Mehmet Rifat Efendi'nin 19151921 yılları arasında görevde bulundukları kaydedilmektedir. 1920-1921 yılları arasında Çarmuzu eşrafindan Abis Ağa lakabı ile anılan, Soyadı Kanunu ile birlikte "Barış" soyadını alan Abdullah Efendi'nin belediye başkanı olduğu ifade edilmektedir. Yukarıda isimleri anılan belediye reislerinden Ömer Efendi'nin üç kez, Feyzullah Efendi'nin iki kez, Ali Bey'in üç kez reislik makamında bulundukları belirtilmektedir. Ancak bu dönemlerde belediyecilik adına hangi hizmetleri yaptıkları bilinmemektedir. Arpacızade Mehmet Rıfat Efendi'nin Birinci Dünya Savaşı sırasında Malatya'da yaşanan buğday kıtlı̆̆ı gidermek için Kâhta bölgesinden buğday getirerek şehirde dağıttığ 1 , az da olsa buğday kıtlığının giderilmesine yardımc1 olduğu ifade edilmektedir. Bu tarihten sonra Malatya Belediye Başkanlığında Hasan Derinkök görülmektedir.

Cumhuriyetle birlikte (20 Nisan 1924 Anayasası 89. Maddesi ile ) müstakil bir vilayet olan Malatya'nın belediye başkanlığına son Osmanlı Beyi Hasan Bey’in seçildiği ve bu görevi 1928 yılına kadar sürdürdüğü bilinmektedir. 1924 yılında il belediyesi unvanıyla kurulan Malatya Belediyesi, bugünkü adıyla Kışla Caddesi üzerinde bulunan iki katı bir hanın ikinci katında iki oda, bir lavabodan oluşan küçük bir dairede faaliyetine başlamıştır. Daha sonra sırasıyla Emir Ahmedoğlu Hanı, İsa oğlunun Hanı ve Şirket Hanı'nda faaliyet göstermiş, 1938 yılında Vilayet binasının doğusunda yapılan kendi binasına taşınmıştır. Şehir merkezindeki bu binada yetmiş bir yıl faaliyet gösteren hizmet binası, 31 Ocak 2009 tarihinde yıkılmış; temeli 2004 yılında atılıp 2009 yılında tamamlanan ve şehrin batısında bulunan yeni Belediye Sarayı'na taşınarak burada hizmet vermeye başlamıştır.

Malatya Belediyesi, Bütün şehir yasasına dek 83 mahallede yaşayan 402 bin nüfusa, 22 bin hektarlık mücavir alanda hizmet vermiştir. 13 ilde büyükşehir ve 26 ilçe kurmayı öngören 2012 tarihli 6360 sayıl1 yasayla belediye anakent belediyesine dönüştürülmüştür. Bu Yasayla Malatya ilinde, ekli (9) sayılı listede belirtilen belediyeler (Dilek, Şahnahan, Topsöğüt, Bindal) ve köyler (Duranlar, Duruldu, Fatih, Göktarla, Karahan, Kendirli, Kırkpınar, Mahmutlu Merkez, Özal Merkez, Samanköy, Suluköy Sütlüce Tepeköy Tohma ve Topraktepe ) ile aynı listede yer alan Malatya Belediyesinin mahalleleri, (Abdülgaffar Aşağıbağlar, Atatürk, Bahçebaşı, Bentbaşı ,Cemal Gürsel, Cevatpaşa, Cumhuriyet, Çarmuzu, Çavuşoğlu, Çilesiz, Çukurdere, Fatih, Gazi, Hoca Ahmet Yesevi, İlyas, İnönü, Karakavak, Kaynarca, Kiltepe, Koşu, Koyunoğlu, Melekbaba, Özalper, Salköprü, Samanl1, Seyran, Su, Şeyhbayram, Tecde, Turgut Özal, Yaka, Yavuz Selim, Yeni, Yeşilkaynak ve Zaviye ) Yeşilyurt ilçe sınırlarına dâhil edilerek Yeşilyurt Belediyesine katılmıştır. Yeşilyurt ilçesinin merkezi, Malatya Belediyesinden Yeşilyurt ilçesine katılan mahalleler olarak değiştirilmiş̧tir.

Malatya ilinde, ekli (10) sayılı listede belirtilen köyler (Bağtepe, Bulgurlu, Çamurlu, Firıncı, Göller, Hacıhaliloğlu Çiftliği, Karagöz, Karakaş Çiftliği, Karaköy, Üzümlü, Alhanuşağı, Bulutlu, Çolaklı, Düzyol, Gülümuşağı, Hacıyusuflar, Hisartepe, Kamıştaş Kapıkaya, Karatepe, Merdivenler, Pelitli, Selvidağ, Tanışık, Tokluca, Uluköy, Yenice ve Yeniköy) ve belediyeler (Hanımınçiftliği Bld., Orduzu Belediyesi, Beydağı 
Belediyesi, Erenli Belediyesi Yaygın Belediyesi) ile aynı listede yer alan Malatya Belediyesinin mahalleleri (Akpınar Aslanbey Ataköy Başhank Battalgazi Beydağı Beylerbaşı Büyük Hüseyinbey Büyük Mustafapaşa Cevherizade Cirikpınar Çöşnük Dabakhane Ferhadiye Fırat Göztepe Hacıabdi Halfettin Hamidiye Hasan Varol Hidayet İskender İsmetiye İstiklal İzzetiye, Kavaklıbağ Kernek Kırçuval Küçük Hüseyinbey Küçük Mustafapaşa Niyazi Nuriye Paşaköşkü Sancaktar Saray Sancıoğlu Selçuklu Şehit Fevzi Şıkşık Şifa Tandoğan Taştepe Uçbağlar Yamaç Yenihamam Yıldıztepe Zafer), Battalgazi ilçe sınırlarına dâhil edilerek Battalgazi Belediyesine katılmıştır. Battalgazi ilçesinin merkezi, Malatya Belediyesinden Battalgazi ilçesine katılan mahalleler olarak değiştirilmiştir.

30 Mart 2014 seçimlerinin ardından da Malatya Belediyesi artık Büyükşehir statüsüne geçerek hizmet alanı tüm il sınırları haline gelmiştir. Böylece hizmet alanı 1.241.000 hektara, hizmet edilen nüfus 750.000'e yükselmiştir. Tablo.1 Malatya ilçelerinin kent merkezine olan uzaklıklarını göstermektedir.

TABLO.1. MALATYA İLÇELERININ KENT MERKEZINE OLAN UZAKLIKLARI

\begin{tabular}{|l|c|}
\hline \multicolumn{1}{|c|}{ ILÇE } & MERKEZE OLAN UZAKLIK (km) \\
\hline Akçadağ & 38 \\
\hline Arapgir & 120 \\
\hline Arguvan & 72 \\
\hline Battalgazi & 9 \\
\hline Darende & 112 \\
\hline Doğanşehir & 91 \\
\hline Doğanyol & 59 \\
\hline Hekimhan & 85 \\
\hline Kale & 42 \\
\hline Kuluncak & 116 \\
\hline Pütürge & 73 \\
\hline Yazıhan & 43 \\
\hline Yeşilyurt & 14 \\
\hline
\end{tabular}

Tablo.1'de de görüleceği üzere Malatya kentinin ilçeleri son derece dağınık bir yerleşime sahiptir. Bu durumda ölçek ekonomilerinden kaynaklanacak olumlu katkıların oluşmamasına neden olmaktadır. Aksine bu durum özellikle hizmet maliyetlerini arttırıcı bir durum oluşturacaktır.

\subsection{KENT PLANLAMASI}

Malatya kenti planlaması 1930'lu yıllara kadar uzanan bir geçmişe dayanır. O dönemde Ankara kent planlaması için Türkiye'ye gelmiş olan ünlü alman kent Plancısı Jansen'in destekleriyle 4 ana sanayii tesisinin etrafında 30.000 nüfuslu bir bahçe şehir modeliyle düzenlenmesine karar verilmiştir. Bu sanayi tesisleri kente girişten merkeze doğru sırasıyla Şeker fabrikası, vagon fabrikası, mensucat fabrikası ve tekel fabrikasidır.

Ancak ne yazık ki bu yaklaşım iller bankasının 1954 yılında yaptığı planla değişikliğe uğramış kentin gelişimi doğuya Elazığ yönüne kaydırılarak bugünkü ana ulaşım arterleri olan Fuzuli caddesi, Turgut Temelli caddesi vb kullanıma açılmıştır. 
Uzun bir dönem bu doğrultuda gelişim gerçekleştirildikten sonra bazı plan değişiklikleriyle 1989 yılında bulgurlu, Çamurlu ve İnönü Üniversitesi yerleşim alanı mücavir alan olarak plan sınırlarına dahil edilmiştir. Son seçim döneminde ise tüm il sınırlarının plan sınırlarına dahil edildiğini görmekteyiz.

Kentler genellikle iki şekilde büyüme gösterirler. Yayılarak büyüme ve yükselerek büyüme. Yayılarak büyüme, kentin nüfus artışına paralel bir şekilde bulunduğu fiziki mekânın dışına taşarak yayılması şeklinde gerçekleşirken, yükselerek büyüme fiziki mekân sabitlenerek mevcut dar alan üzerinde yüksek binalar, gökdelenler ile birlikte bazı ulaşım ve depolama işlemlerin yeraltına alınması şeklinde gerçekleşmektedir (Altan, 2010).

Malatya'nın birinci derecede deprem kuşağında olmasının da etkisiyle Beydağlarının eteklerinde doğubat1 istikametinde sert zemin üzerinde yayılarak büyüdüğü söylenebilir. Şimdilik "uydu kent" şeklinde görülen Beydağı yerleşkesi (TOKİ Evleri) Yıldıztepe, Üniversite yerleşkesi, batıda Yakınca yerleşkesi Malatya'nın orta ve uzun vadede yayılma alanlarına işaret etmektedir.

Tarih boyunca coğrafi açıdan nüfus ve yapı yoğunlaşmaları anlamına gelen kentlerin, değişen ulaşım ve iletişim koşulları dikkate alındığında, zamanla daha geniş, bir alana yayılarak seyrek yerleşeme eğilimine yöneleceği söylenebilir (Altan, 2010).

Diğer taraftan çağdaş, planlama ilkeleri, mal ve hizmet üreten kuruluşların yerleşme merkezlerinin dışına çıkarılmasını, kentsel hizmetlerin ise kırsal alanlara da götürülmesini amaçladığından önümüzdeki süreçte kentlerle köyler arasındaki mesafe azalma eğilimine girebilir. Bu durumda köy - kent ayrımı önemli oranda anlamını yitirebilir.

Malatya'nın nasıl bir yerleşke oluşturması gerektiğine dair ileri sürülen görüşlerden biri "Malatya Bölgesel Orta Merkez Gelişim Planı Çerçeve Çalışması" başlıklı bir raporda dile getirilmiştir (Koçer, 2007). Bu çalışmada Malatya için Kömürhan'dan başlayarak, Akçadağ'a uzanan yaklaşık 90 km'lik bir hat boyunca alt merkezler oluşturulması önerilmiştir. Çöşnük-Karakavak hattını kent merkezi olarak tanımlayan çalışma, bu merkeze ek olarak beş, alt merkez oluşumu önermiştir. Bu alt merkezler sırasıyla; Kale-Kömürhan Alt Merkezi, Üniversite- iftlik Alt Merkezi, Akçadağ Alt Merkezi ve Eski Malatya Alt Merkezi ile Gemici arşıyaka Alt Merkezidir.

\subsection{NÜFUS YAPISI}

Adrese dayalı nüfus kayıt sistemine göre 31 Aralık 2010 tarihi itibariyle Malatya'nın nüfusu 740643 kişi olarak tespit edilmiştir.. 2012 y1lı itibariyle nüfus 750.000'i aşmış bulunmaktadır. Bu nüfusun \%49.83'ü erkek, \%51.17'si kadındır. Malatya, bu değerle Türkiye toplam nüfusunun \%1'ini oluşturmaktadır. Malatya, 81 il arasından toplam nüfus bakımından 29., kent nüfusu bakımından ise 26. siradadır. Yapılan bir nüfus projeksiyon çalışmasına göre Malatya nüfusu 2020 y1lında 940.364, 2030 y1lında ise 1.136.676'ya yükselecektir. 2010 yılında nüfusun yaklaşık \% 65'i şehirde yaşarken bu oran 2020 yllında yaklaş1k \%71'e, 2030 yılında ise yaklaşık \% 75'e yükselecektir (Söyler, 2006). Malatya nüfusunun yıllar itibariyle değişimi Tablo 2'de verilmiştir.

TABLO 2.:MALATYA KENTİ NÜFUS DEĞİŞIMI (1927-2010)

\begin{tabular}{|c|c|c|}
\hline & \multicolumn{2}{|c|}{ NÜFUS } \\
\hline SAYIM YILI & TÜRKIYE & MALATYA \\
\hline $\mathbf{1 9 2 7}$ & 13648270 & 305785 \\
\hline $\mathbf{1 9 3 5}$ & 16158018 & 410162 \\
\hline $\mathbf{1 9 4 0}$ & 17820950 & 418473 \\
\hline
\end{tabular}




\begin{tabular}{|c|c|c|}
\hline $\mathbf{1 9 4 5}$ & 18790174 & 28660 \\
\hline $\mathbf{1 9 5 0}$ & 20947188 & 483568 \\
\hline $\mathbf{1 9 5 5}$ & 24064763 & 342835 \\
\hline $\mathbf{1 9 6 0}$ & 27754820 & 394172 \\
\hline $\mathbf{1 9 6 5}$ & 31391421 & 452624 \\
\hline $\mathbf{1 9 7 0}$ & 35605176 & 510979 \\
\hline $\mathbf{1 9 7 5}$ & 40347719 & 574558 \\
\hline $\mathbf{1 9 8 0}$ & 44736957 & 606996 \\
\hline $\mathbf{1 9 8 5}$ & 50664458 & 665809 \\
\hline $\mathbf{1 9 9 0}$ & 56473035 & 702055 \\
\hline $\mathbf{2 0 0 0}$ & 67803927 & 853658 \\
\hline $\mathbf{2 0 1 0}$ & 73722988 & 740643 \\
\hline
\end{tabular}

Kaynak: TUIK verilerinden derlenmiştir.

Tablo.2. dikkatle incelendiğinde Malatya nüfusunun iki kez çok ciddi oranlarda düşüş anlamında farklılık gösterdiği görülebilir. Bunlardan ilki 1950 ve 1955 yılları arasındaki farktır. Bu farkın sebebi Malatya ilinin ikiye bölünerek Adıyaman ilinin kurulmasıdır. İkincisinde ise büyükşehir olmaya çalışmanın bir yan etkisi olarak şişirilmiş nüfus sayımıdır. İçişleri bakanlığı bu tür sayımlar yüzünden bu sayımları geçmiş̧e revize etmek zorunda kalmış ve bu ve benzeri sorunlar nedeniyle adrese dayalı nüfus sayımına geçilmiştir. Bu yeni sistemde sayım da sonuçlar arasındaki farklılı̆̆ın açılanması açısından önemli olmaktadır.

Malatya kentinin nüfus dağılımına ilişkin en önemli durumlardan biri de nüfus dağılımının son derece dengesiz olmasıdır. Bu önümüzdeki dönemlerde özellikle hizmet dağılımı açısından önemli sorunlar çıkaracaktır. Tablo.3. Malatya merkez ilçeler ve diğer ilçe merkezlerine ilişkin nüfus verilerini göstermektedir.

TABLO.3. MALATYA KENTİ İLÇE NÜFUSLARI

\begin{tabular}{|l|l|l|l|}
\hline & Toplam & i̇l/liçe Merkezleri & Belde/köyler \\
\hline Toplam & 740.643 & 480.14 & 260.499 \\
\hline Merkez & 469.650 & 401.705 & 67.945 \\
\hline Akçadağ & 30.114 & 7.564 & 22.550 \\
\hline Arapgir & 11.054 & 6.152 & 4.902 \\
\hline
\end{tabular}




\begin{tabular}{|l|l|l|l|}
\hline Arguvan & 8.289 & 1.865 & 6.424 \\
\hline Battalgazi & 29.688 & 16.979 & 12.709 \\
\hline Darende & 32.192 & 9.424 & 22.768 \\
\hline Doğanşehir & 41.464 & 10.891 & 30.573 \\
\hline Doğanyol & 4.886 & 1.663 & 3.223 \\
\hline Hekimhan & 24.353 & 7.588 & 16.765 \\
\hline Kale & 6.341 & 1.826 & 4.515 \\
\hline Kuluncak & 9.100 & 1.940 & 7.160 \\
\hline Pütürge & 20.262 & 2.628 & 17.634 \\
\hline Yazıhan & 16.398 & 2.117 & 14.281 \\
\hline Yeşilyurt & 36.852 & 7.802 & 29.050 \\
\hline
\end{tabular}

Kaynak: Adrese Dayalı Nüfus Kayıt Sistemi (ADNKS) 2010 Nüfus Sayımı

Gezer ve arkadaşlarının (2011: 29) yapmış oldukları bir çalışmada Malatya'nın nüfus durumu ve iç göç durumuna ilişkin önemli tespitler söz konusudur. Buna göre Malatya'da kent içine en çok göç veren ilçeler sırasıyla Akçadağ, Yeşilyurt ve Hekimhan'dır. İl dışına göç veren ilçeler ise Pütürge, Darende ve Akçadağ'dır. Bu üç ilçenin de kent merkezine uzak ilçeler olması merkez-çevre ilişkisinde bir uyumun olmadığını göstermektedir. Özellikle son dönemlerde kentsel ve bölgesel kalkınma modellerinde üzerinde en çok vurgu yapılan bu durumun Malatya için geçerli olmadığı söylenebilir.

Malatya kentine yönelik olarak göç nedenlerine bakıldığında öncelikle tarımda makineleşme sürecinin başlamasıyla çevre il, ilçe ve köylerden kente gelenler öncelikli göçmenlerdir. Bunlara zamanla Karakaya, Atatürk, Keban gibi büyük baraj göllerinin suları altında kalan köylerden Malatya'ya gelenler eklenmiştir. 1980 sonrasında terör nedeniyle boşaltılan köylerden kente göç edenler de önemli bir nüfus oluşturmaktadır. Bunun dışında özellikle 2. Ordunun merkezinin Malatya’ya kaydırılmasıyla ve mevsimlik işçilerin nüfus kaymaları da kentteki nüfus hareketliliğinin temel nedenleri arasında sayılabilir.

\subsection{GELENEKSEL ŞEHİRDEN BÜTÜNŞEHİRE MALATYA'DA DEĞIŞ̧IMIN SANCILARI}

Malatya kentinin kentleşmeye ilişkin temel sorunları şu şekilde sıralanabilir:

- Kentsel Sorunlar ve kent merkezinde kontrolsüz büyüme

- Kırsal Gelişme ve Göçler

- Kaçak Yapılaşma ve Gecekondu

- Afetlere Dayanıksız Kentleşme

- Kentsel Altyapı ve Çevre Sorunları

- Kentsel Ulaşım Sorunları

- Planlama Sisteminden Kaynaklanan Sorunlar

- Yerel Yönetimlerin Kapasitelerindeki yetersizlikler

Bu sorunları kısaca açacak olursak şunları söylemek mümkündür:

Malatya kentine yönelik genel bir bakış yaptığımızda kuru kayısı üretim ve ihracatında dünya çapında bir konum yakaladığı görülür. Kent aynı zamanda sanayi üretiminde de Türkiye ortalamasının üzerinde bulunmaktadır. Kurulu üç organize sanayi bölgesi, organ nakli konusunda önemli bir konumda bulunan araştırma hastanesi ile önemli bir konumda bulunmaktadır. 
Buna karşın kentte hala ciddi bir istihdam sorununun olması ilçeler arasında gelişmişlik farklarının çok yüksek olması, ayrıca nitelikli işgücü konusunda çekilen sıkıntılar son derece önemlidir. Kentsel dönüşümün henüz emekleme aşamasında olması, sürdürülebilir bir kentleşme yapısına ulaşılamaması da son derece önemli bir durumdur. Kentin en önemli sorunlarından birisi de trafiktir. Kentin bir ulaşım master planının olmaması bu sorunun boyutlarını daha da büyütmektedir. Kent merkezinde günün her saatinde kilitlenen trafik, sürekli tek yöne dönüştürülen cadde ve sokaklar da bu sorunu çözmeye yeterli olamamaktadır. Beylerderesi'nde açılan yolda raylı sistem için bir düzenleme yapılmamış olması da önemli bir eksiktir.

Kentsel planlama açısından da önemli yanlışlar yapıldığı görülmektedir. Örneğin bölge eğitim hastanesinin yerinin yanlış seçimi, Niyazi Mısri caddesinin hem yol hem de yerleşim açısından yanlış planlaması, Fahri Kayahan Bulvarının ve bölgesinin yanlış planlanması, organize sanayi bölgesinin kentin gelişim yönü dikkate alınmaksızın projelendirilmesi, kent merkezinin alt merkezler düşünülmeksizin tek parça planlanması ilk etapta sayılabilecek olanlardır.

Malatya kenti TRB1 Bölgesini oluşturan Elâzı̆̆g, Bingöl ve Tunceli illeri ile Doğu Anadolu Bölgesinin en bat1 ucunda, Yukarı Firat havzasını kapsamaktadır. Görece batıda olmaları, yükseltilerin görece daha az olması, İskenderun Körfezi doğrultusunda uzanan koridor ucunda yer almaları ve Fırat nehri, kolları ve üzerinde yer alan baraj göllerinin olumlu etkileriyle iklim koşulları açısından daha elverişli, tarım arazileri açısından daha zengin ve gelişmişlik açısından da daha ön sıralarda yer almaktadır.

Malatya kenti 2003 yılında yapılan gelişmişlik sıralamasına göre 41. Sırada iken 2011 yılında yapılan sınıflandırmada 42. Sıraya gerilemiştir. URAK'ın yaptığ rekabetçilik endeksinde 28. Sırada görülen Malatya İTÜ'nün araştırmasında 4. Düzeyde gelişime dirençli kentler sınıfında olduğu görülmektedir (Fırat Kalkınma Ajans1, 2013). Malatya kent merkezinde görülen sıkıntı ilçelerde çok daha vahim düzeydedir. Öyle ki merkez ilçenin Türkiye'de ilk 100 de olan gelişmişlik düzeyi merkezden uzaklaştıkça hızla düşmektedir. Örneğin artık merkez ilçe olarak tanımlanan Yeşilyurt'un gelişmişlik düzeyi Türkiye'de 353, en uzak ilçelerden bir olan Pütürge'nin sıralaması ise 823. Sıradır. Bütün kent yasasıyla bu geri kalmışlık düzeyinin daha da artması beklenmektedir. Kentin bütün olumlu etmenlere karşın sosyo-ekonomik gelişme düzeyinde beklenilen sıçramayı yapamamasının en temel nedeni diğer yerleşim merkezlerinin merkeze olan uzaklı̆̆ gibi görünmektedir.

Malatya kenti tarımın yanında hayvancılı̆̆ın da önemli bir gelir kalemi olduğu yerlerden biridir. Her ne kadar küçük ölçekli ev tipi hayvancılık tesisleri bulunsa da, bunlar yadsınamaz sayıda bulunmaktadır. Ancak yeni yasayla tüm il sınırlarının kent sınırı olarak kabul edilmesi ve kent sınırlarında hayvancılığa izin verilmesinin yasalarla mümkün olmaması hayvancılığı bekleyen en önemli tehlikelerdendir. Bu sorunun çözümünde organize hayvancılık bölgeleri ivedilikle düşünülmelidir.

Malatya'da kırsal kesimde görülen sosyo-ekonomik geri kalmışlığın çözümünde kullanılabilecek olan KÖYDES, Köylere Hizmet Götürme Birlikleri, İl ve İlçe Özel idarelerinin artık olmayışı önemli bir sıkıntı gibi görülmektedir ve kısa vadede çözülecek gibi de görülmemektedir.

\section{SONUÇ}

Yeni Bütün şehir yasası ile büyük şehir statüsüne kavuşan diğer kentlerde olduğu gibi de Malatya kentinin bu yasadan büyük ölçüde olumsuz etkilenmesi kaçınılmaz gibi görünmektedir. Bu olumsuzlukların en aza indirgenebilmesi için aşağıda sıralananlar öncelikli olarak hayata geçirilmelidir:

- Malatya için bir "Kent Vizyonu" belirlenmelidir.

- Kapsamlı bir "Kentsel Gelişim Planı" hazırlanmalı, bu plan çerçevesinde Malatya'nın gelişimi için stratejik amaçlar, genel hedefler, önemli projeler vs ortaya konulmalıdır.

- Kamu, özel sektör ve STK'ların da katılımıyla Malatya'nın "Kentsel Gelişim Stratejik Planı" hazırlanmalıdır.

- $\mathrm{Bu}$ sürecin doğru işletilebilmesi için bir süredir hazırlık çalışmaları yürütülen 1/100 000'lik “TRB1 Bölge Planı"nın Malatya'nın gelişim alanları, vizyonu ve gelecek projeksiyonlarına uygun olarak hazırlanması, sürecin katılımcı bir şekilde yürütülmesi ve verilerin doğru toplanması için özel hassasiyet gösterilmelidir. 
- Yine hazırlıklarına başlanan ve Malatya'nın ileriye dönük konut, sanayi, tarım, turizm, sağlık, eğitim, ulaşım vb alanlarının belirlenmesini sağlayacak olan 1/25 000'lik "Malatya Çevre Düzeni Planı"nın bölge planıyla uyumlu ve ildeki tüm kesim ve kurumların katılımıyla hazırlanması sağlanmalıdır.

- Bölge ve il çevre düzeni planından sonra bu planlarla uyumlu olarak arazilerin imar durumu, bölge tipleri, yapı yoğunluğu, ulaşım hatları, park alanları vb göstermek ve uygulama imar planlarının hazırlanmasına esas olmak üzere 1/2000 ya da 1/5000 ölçekli "İmar Ana Planı" (İmar Master Planı) hazırlanmalıdır. $\mathrm{Bu}$ aşamadan sonra ise kullanılacak alanla ilgili daha çok ayrıntı veren 1/1000 ölçekli "Uygulama İmar Planları" hazırlanmalıdır. İlde bu aşamadan önceki planlar olmadığı için uygulama imar planları maalesef "parça bütün ilişkisinden" bağımsız bir şekilde uygulanmaktadır. $\mathrm{Bu}$ ise kentin plansız bir şekilde gelişmesine yol açmaktadır.

- $\mathrm{Bu}$ çalışmalar kapsamında kentin gelişim eksenleri, stratejik sektörleri ve rekabet üstünlügü olan alanlar belirlenmelidir.

- Belirlenen vizyon ve hazırlanan plan çerçevesinde her kurumun görev ve sorumluluk alanları açıkça ortaya konulmalıdır.

- Kentin gelişiminde etkili olan bütün kurumlar için performans kriterleri belirlenmelidir.

- Merkez ilçe ile diğer ilçeler arasındaki aşırı düzeye varmış olan sosyoekonomik gelişmişlik farkını makul düzeye çekecek bir projeksiyon geliştirilmelidir.

- Kent merkezinde ve ilçelerde sosyal zekâ ve iletişim becerisi açısından gelişmiş̧ kadroların yetişmesi için mekanizmalar oluşturulmalı ve bu konuda STK'ların daha aktif olması sağlanmalıdır.

- Türkiye ve dünyadaki gelişmeler takip edilmeli, kentsel ekonomiler ve yerel kalkınma alanında yaşanan değişimler iyi okunmalı ve gelecek döneme yönelik projeksiyonlar buna göre ortaya konulmalıdır. 


\section{KAYNAKÇA}

ALTAN, M., (2010), Kent Dindarlı̆ğ, Timaş Yayınları, İstanbul.

ÇAĞLAR, E. (2006), “Türkiye’de Yerelleşme ve Rekabet Gücü: Kümelenmeye Dayal Politikalar ve Organize Sanayi Bölgeleri”. 1. Yönetişim ve Bölgesel Kalkınma Sempozyumu, Ankara.

DİNÇER, B., ÖZASLAN, M., SATILMIŞ, E., (1996), Illerin Sosyoekonomik Gelişmişlik Sıralaması Araştırması. Ankara: DPT. Bölgesel Gelişme ve Yapısal Uyum Genel Müdürlüğü, Ankara.

Fırat Kalkınma Ajansı (2013), 2014-2023 TRB1 Bölge Kalkınma Planı Taslă̆ı, Fırat Kalkınma Ajansı: Malatya.

GEZER, İ vd. (2011), Malatya: Vizyon 2023, Bilsam Yayınları: Malatya.

KOÇER, A. T., (2007), Malatya Bölgesel Orta Merkez (Bom) Gelişim Planı Çerçeve Çalışması.

SÖYLER, H. (2006), “Sistem Dinamiği Yaklaşımı ile Malatya ilinin Sosyo-ekonomik Gelişim Projeksiyonu, ” İstanbul Üniv. Sosyal Bilimler Enstitüsü Sayısal Yöntemler Anabilim Dalı, Doktora Tezi 